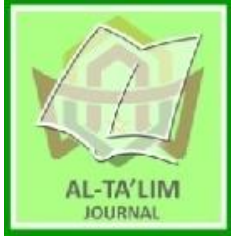

AL-TA'LIM JOURNAL, 27 (1), 2020, (16-29)

(Print ISSN 1410-7546 Online ISSN 2355-7893)

Available online at http://journal.tarbiyahiainib.ac.id/index.php/attalim

\title{
The Strategy of Forming Religious Characters on the Deaf Children: Study at Special Schools in Rejang Lebong
}

\author{
Received: $05^{\text {th }}$ April 2019; Revised: $06^{\text {th }}$ April 2019; Accepted: $27^{\text {th }}$ February 2020 \\ Permalink/DOI: https://doi.org/10.15548/jt.v27i1.588
}

\author{
Ahmad Suradi *) \\ Institut Agama Islam Negeri \\ Bengkulu, Indonesia. \\ E-mail: suradi@iainbengkulu.ac.id
}

\section{Buyung Surahman}

Institut Agama Islam Negeri

Bengkulu, Indonesia.

E-mail:

buyungsurahman@iainbengkulu.ac.id

\section{Mawardi \\ Universitas Syah Kuala Banda Aceh, Indonesia. \\ Email: mawardi19@gmail.com}

\section{*) Corresponding Author}

\begin{abstract}
The study aims to determine the strategy used in forming religious characters on the deaf children in Elemantary Special School. A qualitative method was used where the data taken from observation, interview and document analysis. The result showed that the learning strategy of Islamic religious education in the development of morals for children with special needs in special schools is by implementing expository strategy, adding hours of study using the habituation method. The finding also showed that the supporting factors in the learning process to form moral guidance are the involvement of school's principal who is very concern on the development of students' morals; the teachers who have great patience in dealing with children with special needs. Then, it was also found that there were some inhibiting factors that faced by the school. They were on the absence of a special curriculum for children with special needs, Islamic education teachers who are not teachers who are graduates of special service schools, as well as the lack of supporting facilities as learning media, doing the learning process run monotonously.
\end{abstract}

Keywords: Strategy; religious characters; deaf children

How to Cite: Suradi, A. (2020). The Strategy of Forming Religious Characters on the Deaf Children: Study at Special schools in Rejang Lebong. Al-Ta lim Journal, 27 (1). doi:https://doi.org/10.15548/jt.v27i1.588

\section{INTRODUCTION}

Education is an important factor for the creation of a harmonious life and based on clear values (Galindo et al., 2007; Lipman, 2003). Without education, human life patterns cannot run properly, follow the passions and are far from the ideal values that must be fought for and accounted for. Therefore, teaching knowledge about Islam is very important for all Muslims. This is in line with the concept of the Qur'an in Surah Hajj:3. All humans are in equality to have the right on education and require religious education and science (Harahap, 2019; Mumtahanah, 2011). Basically every human being has the right to have education in order to develop the potential capability. Thus, he or she needs assistance from others who are able to guide him or her. This is no exception for children who have physical deficiencies in the form of partially or partially deformed (abnormal) limbs such as hearing impaired.

Children who have physical or psychological disabilities or differences are often referred to as people with disabilities (Buhler, 2013; Farokhi \& Hashemi, 2011; Hager \& Runtz, 2012). This is usually caused by lack of oxygen at birth which causes brain damage or neurological disorders, which can make a child suffer from brain paralysis (cerebral palsy) (Rafferty, 2008).

Todays, education for the deaf children should be given more attention so that they are not further away from the community, 
because as citizens they have equal right to have education and teaching in accordance with their respective conditions and abilities (Morton, 2000; Powers, 2002; Wilkens \& Hehir, 2008). As for obtaining education for children who have juridical disorders mentioned in Article 5 paragraph 2 of the Law on the National Education System, it states that citizens who have physical, emotional, mental, intellectual and/or social disabilities are entitled to special education (Syahrizal \& Sugiarto, 2013). Provisions in Republic of Indonesia Law Number 20 of 2003 is a foundation for Children with Special Needs because the law explains that children who have special needs need to get the same opportunities as those given to other normal children in terms of education and teaching. Nugroho \& Mareza (2016) mentioned that every citizen has the same right to obtain quality education. Citizens who have physical, emotional, mental, intellectual or social disabilities are entitled to special education.

For those who have disabilities or include the deaf children, the government has provided special schools which is welknown as Sekolah Luar Biasa so that children who have special needs can get education and skills that can be used as provisions for their lives so as not to become a burden for others, especially parents and families, especially to reach his goals (Rahardja, 2016). As the word of God in Q.S.At-Tiin: 4. In the book of commentary Ibn Kathir this verse is interpreted that, this is the object of oath, namely that Allah has created man in the best form and form with perfect stature and normal body members (Katsir, 2004). The Word of God above, God does not discriminate between His creatures (humans), humans are created as well as possible so that before God all humans are equally dependent on their deeds. Therefore, it is true that children with special needs or their physical or mental disabilities need to get the same treatment especially in the field of education. Education plays a very important position to form characters (Avramidis et al., 2000; Cook et al., 2015; Guha et al., 2008; Hastings \& Oakford, 2003). It is specifically for them to get religious education because this education is a necessity for them to perform their worships that are applied in everyday life.

Religious education is a fundamental one that must be given to all students as a provision of life in the world and the hereafter (Afdal, 2008; Holley, 2016; Vermeer, 2010). In the schools, it is given in Islamic religious education that is subjects that are compulsory curriculum to be studied by all Muslim students. Islamic religious education is an effort in the form of guidance and care for students so that after completion of education they can understand and practice the teachings of Islam and make it a way of life (Aat Syafaat, 2008; Nesbitt, 2004)

The importance of studying religion has broad meaning, regardless of one's condition whether he is normal or has physical, mental or behavioral limitations. The deaf children are also entitled to education. Basically, the deaf children face great obstacles in the field of personal, social, and academic formation. Seen from the general character, they tend to have unstable personalities, temperament, moody and others, especially in terms of their understanding of the lessons they receive at school. It must be realized that a teacher should know the characteristics of each student. Educating children with physical, mental or physical characteristics is not the same as educating normal children, because in addition to requiring a specific approach also requires a specific strategy (Aron \& Loprest, 2012; Carta et al., 1991; DeVore \& Russell, 2007; Pivik et al., 2002). This is solely because it relies on the conditions experienced by these children with disabilities. Therefore, a teacher must try to create a pleasant learning atmosphere for all students, because a learning atmosphere that is not exciting and enjoyable for students will usually bring teaching and learning activities that are less harmonious, especially for deaf children (Swanwick \& Marschark, 2010; Wauters \& Knoors, 2008). A teacher must really have a specific strategy so that students who need guidance and special treatment can understand the lesson well. 
Good classroom management will influence good teaching and learning interactions, such as learning goals can be achieved without finding significant obstacles. In addition, the success of learning must be supported by the selection of the right strategy with the lessons to be delivered, also supported by adequate learning resource media so that the lessons delivered are achieved according to the intended educational goals. There are different things the writer witnessed during the initial survey, children with special needs in special school in Rejang Lebong, especially those with hearing impairment, they display something that attracts attention, where they have good character towards God with the habit of praying before and after learning, having good morals to teachers and older people by always shaking hands and kissing the hands of older people, they are also very concerned about others as evidenced by the quick response when seeing teachers who need help without being asked, they also care about the environment. Dispose of trash in its place, school infrastructure is well maintained. While the writer who is actually a lecturer and a teacher of Islamic Education in public schools with the majority of their students under normal conditions, but still always finds obstacles in providing moral guidance. For that reason, the writer is interested in wanting to know how the strategy is implemented in instilling morals for children with special needs in Special Schools.

\section{METHOD}

A qualitative approach research was used. This research approach is a research method that is based on the philosophy of postpositivism, used to examine natural conditions of objects where the researcher is a key instrument. The study was conducted at Elemantary Special School for 3 months, starting on February 11 until April 11, 2019.

While the type of research used is case study research. Case study research is research that seeks to describe a phenomenon, event, event that is happening right now. Case study research focuses on the actual problem as it was when the research took place. Through descriptive research, researchers try to describe the events and events that are the center of attention without giving special treatment to those events. The respondents of this study were the principal, teachers and deaf students at Special Schools in Rejang Lebong, by means of observation, interviews and documents.

\section{RESULTS AND DISCUSSION}

\section{Learning Strategies for the Deaf Children}

There are actually so many learning strategies, the following are among the strategies that can be used by teachers to enable students in the learning process for children with hearing impairment according to Generals, Strategies commonly used for children with disabilities include; heuristic, expository, classical, group, individual, cooperative, and behavior modification strategies (Dermawan, 2013). 1) The Heuristic Learning Strategies. Heuristic strategies are teaching and learning strategies that work around so that aspects of the components forming instructional systems lead to activating students can also be interpreted as reason in the work or practical instructions that can help shorten the path of problem solving (Seriti et al., 2013). 2) The Expository Learning Strategies. According to Jaya (2012) revealed that expository learning strategy is a form of teacher-oriented learning approach. It is said so because in this strategy the teacher plays a very important or dominant role. Almost in line with Safriadi's statement that in expository learning the teacher presents the material in a form that has been prepared neatly, systematically and completely so that students stay listening and digesting it in an orderly and orderly manner (Safriadi, 2017). 3) The Cooperative Learning Strategies. Cooperative learning strategy is a series of learning activities carried out by students in certain groups to achieve the learning objectives that have been formulated. There are four important elements in cooperative learning strategies, namely the presence of participants in the group, the existence of group rules, the learning effort of 
each group member, and the existence of objectives that must be achieved (Johnson \& Johnson, 2011; Slavin, 1987). So, the interesting thing from cooperative learning strategies is that there is hope that in addition to having a learning impact, that is in the form of an increase in student achievement (Student achievement) also has an accompanying impact such as social relations, acceptance of students considered weak, selfesteem, academic norms, respect for time, and like to give help to others. 4) The Collaborative Learning Strategies. The collaborative learning is a learning strategy where students with multilevel variations work together in small groups towards one goal. In this group the students help one another. So the collaborative learning situation there is an element of positive dependence to achieve success. 5) The Behavior Modification Learning Strategies. Behavior modification is the application of operant conditioning learning theory to change behavior. Operant conditioning discovered by B.F Skinner refers to the relationship between the environments that result in specific behavioral changes. Assumptions relating to behavior modification include the following. (1) Behavior is something that is learned. (2) Behavior is not permanent but can be trained, taught and changed or modified. (3) Most of the behavior is the result of certain stimuli, for example when a mosquito bites, people will be moved to hit it. Behavior does not occur randomly, but because of a stimulus. (4) Behavioral management programs should be specific. for each behavior to be modified. (5) Behavioral management programs must be focused on the child's environment (Safriadi, 2017).

Mahabbati (2014); Rahayu (2013) stated some special principles that must be considered in learning for children who have deficiencies in this case deaf, these principles are: 1) Position in conveying and explaining learning to students should deal with students (face to face) and do not turn their backs on students because deaf students will try to understand what the teacher explained through reading utterances. 2) In an inclusive or regular class, the deaf students should be placed in a sitting position in front so that they can understand the teacher's words when explaining and should be placed with students who have good hearing so that they can help smooth learning. 3) The deaf students have obstacles in capturing teacher explanations due to lack of hearing, therefore teachers should provide an explanation slowly, clearly, loud voice, simple sentences or language used and record important things on the board. The teacher should also pay attention to the direction of the ray of light, so that the deaf student is not dazzled by the teacher's lip movements and expression. 4) The use of visual aids should be sought by the teacher in learning to facilitate students' understanding of the deaf to the material presented because deaf students are known as visual children. 5) Avoid using the lecture method often because deaf students experience hearing impairments that make it difficult to understand the teacher's words. Teachers should use more visual methods such as demonstrations, role playing and so on. 6) The teacher needs to modify or simplify the use of language in verbal material so that deaf students can understand the material presented. 7) Provide additional vocabulary and ensure that deaf students understand correctly the terms that the teacher uses because deaf students are poor in vocabulary or less understanding in vocabulary compared to other regular students.

Based on the explanation above, it is clear that deaf children are very complex in terms of learning, in addition to problems with their sense of hearing, they are also poor in vocabulary, difficult to understand material in the form of verbal and can not learn with the conditions of the room that dazzle their eyes. So for teachers who teach inclusion classes that are deaf children or indeed deaf classes, must really pay attention to the special principles of learning for deaf children as described above. 


\section{The Forming the Religious Character of the Deaf Children in Special Schools}

Islamic Education is a subject that is in public schools including the Special Schools in Rejang Lebong, Bengkulu. Based on documentation and interview data, the curriculum implemented at this school uses the 2013 curriculum, where Islamic religious education gets a three-hour portion every week for all classes. The teacher who teaches Islamic Education at Special School in Rejang Lebong is not a teacher who is based on Special School Education, but the teacher is a teacher based on Islamic Education who comes from State Islamic Institute of Curup graduates, and as a support for teachers who will teach in Special School then the school provides special training for teachers who will teach.

The purpose of Islamic education at the Pecial School in Rejang Lebong refers to the realization of the vision and mission of the school, namely Excellence in the field of skills to equip students for independence based on cultural and religious values. This is the uniqueness of the implementation of the curriculum in schools in learning as an effort to develop morals, so to achieve this vision Special Schools in Rejang Lebong has the following mission: 1) Improve the quality that is relevant in special education and special services; 2) Instilling belief/Aqeedah through the practice of religious teachings (EES of Rejang Lebong Document, 2019).

The implementation of Islamic education learning carried out at special Schools in Rejang Lebong based on the 2013 curriculum with a total of three hours of learning in each class, while teachers who teach Islamic education subjects are teachers of State Islamic Institute of Curup graduates who are then equipped with special knowledge to communicate with students with special needs, this aims to realize the vision and mission of the school in which there is moral guidance, and Islamic education teachers are the teachers who are most in touch with it, so the role of Islamic religious teachers is very dominant, both in terms of providing material in class and the implementation of religious activities carried out.

\section{Expository Learning Strategies Using Modeling Methods and Eercises}

The deaf Children have limitations in terms of hearing, some are low, moderate, and some are totally unable to hear at all so special strategies are needed to deliver learning material; especially there are students who have doubts that are deaf and dumb. Delivering subject matter to deaf children requires a special way that is better known as commtal or total communication, besides that a teacher must really prepare adequate media to convey the material, such as pictures and videos related to the material even to teach about daily activities days like eating and eating should use pictures and at the time of evaluation or examination it is suggested that the questions given use more images

Based on the explanation from the teachers above, it seems that the expository strategy is indeed very suitable for use in the learning process for students with special needs, especially for people with hearing impairment, because the principle in this learning strategy a teacher really prepares everything related to the material to be taught, as expressed by Safriadi (2017) that, in expository learning, the teacher presents the material in a form that has been prepared neatly, systematically and completely so that students stay listening and digesting it in an orderly and orderly manner. Almost the same as the expression of Ariani (2017) that expository learning strategy as a direct learning strategy (Direct Instruction), because learning is delivered directly by the teacher, students are not required to find the material because the subject matter seems to be ready and prepared by the teacher.

The learning method used to carry out the expository learning strategy is very appropriate when the modeling and training methods are used where the teacher does not explain much verbally but the teacher shows more pictures, then students take turns 
implementing the tasks given by the teacher such as showing the exact picture they have to select, this can be seen when the teacher provides learning about morals. The results of the study, that the modeling and assigning methods or exercises are very appropriate for students with hearing impairment because they are more interested in paying attention to the pictures that are displayed, and when they are instructed to choose the most appropriate picture, they look very enthusiastic, besides that there is a habit interesting thing that was done by Islamic Education teachers at Special Schools in Rejang Lebong, that students were assigned to paste the pictures given by the teacher to their notebooks that had previously been representative of students photocopied the pictures in the administration room, and that they could do with well.

The presentation from the teacher council regarding the use of modeling methods for deaf students is very effective, because this method provides more concrete learning and is easily understood by students, they can use the senses that they are the mainstay of vision besides teachers who provide explanations using total communication and voice hard, their interest in the image makes them very enthusiastic to follow the learning and carry out the tasks given by the teacher to them, so it is appropriate if we refer to the old adage, if students have enjoyed the lesson, then they will automatically love the teacher who teaches it, outside Usually it can be felt by the teacher is when his students are very obedient, and shows good morals to the teacher both in class and outside the classroom, from the results of interviews and observations conducted answered that there are advantages that are felt when the teacher provides learning with and using modeling methods and exercises.

So, the modeling method basically expresses the ideas thought by the teacher and then can later be imitated or demonstrated by students through examples in the form of pictures or actions of a show. This method is very effective for students with special needs, especially those with hearing impairment, to create conducive learning situations and produce maximum learning outcomes.

\section{Adding Class Hours with the Habituation Method}

The method of habituation if done early on, according to Ihsani et al. (2018), will bring hobby and the habit will become a kind of custom so that it becomes an inseparable part of his personality, in developing the attitude the habituation method is quite effective. Moral development for children with special needs at Special Schools in Rejang Lebong, In addition to being done in the classroom at a predetermined hour, Islamic education teachers also do it outside of class hours by using the habituation method. Moral development with the habituation method consists of fostering morals to God, fostering morals to beings and fostering morals to the environment.

\section{Moral Guidance to Allah}

The Elementary Speacial School of Rejang Lebong carries out the moral character of students to Allah with the habituation method including:

\section{The habit of memorizing short letters}

The Koran is the greatest miracle revealed to the Prophet Muhammad, as a complete book from the previous book which has virtues for anyone who reads, learn let alone able to memorize it. One of the miracles that we feel from the Koran is that, although speaking Arabic, but whoever the person is, whatever the nation and language will be given convenience for those who want to learn it, even Allah gives convenience for those who are serious about memorizing it, as proven today few people are able to memorize the whole contents of the Koran, even children who are 5 years old Allah gives ease to memorize the Koran. This is proof that Allah sent him down and Allah also guarded him. Currently there are many attempts made by state and private educational institutions that encourage students to memorize the Koran, as well as those done by Special Schools in Rejang Lebong, although the 
desired target is not the same as public schools especially those based on Islam, but this school tries to targeting students to memorize short letters in the Koran, this is related to the limitations of students whose backgrounds have physical or even mental deficiencies.

The method of teaching memorizing short letters that is appropriate for children with special needs is the classical method, as revealed by Maskur (2019) . That teaching in a classical way will encourage students to be more enthusiastic. There is a nuance of learning that is fresher than the individual model. The classical way is also effective and efficient for teachers to convey theories, both about makhroj, the nature of letters, reading laws, and other aspects of recitation. Other positive effects, students will gain additional experience from the teacher, how the teacher reacts with students, train sensitivity to reading errors made by students and how the teacher straightens them and so on, during the learning process runs, each teacher should try to make students use the time learn. Aim to continue to use free time by repeating readings on lessons that are not yet mastered. Familiarize children to memorize the Koran, especially in short letters the right method is done classically, where the teacher as a mentor reads slowly then followed by children and it is done repeatedly, especially for children who have special needs.

\section{The habit of participating in Islamic holidays}

In addition to learning that is carried out formally with a predetermined schedule, it turns out that getting children used to participating in Islamic holidays has a positive impact on their moral development, as is done by Special Schools in Rejang Lebong, always holding religious activities in accordance with certain moments such as commemoration activities of the Prophet Muhammad's Birthday, commemoration of Isra 'Mi'raj in which there is moral guidance especially in the example of the Prophet. According to Rahmi (2019), instilling morality with a story says that, example is important in moral education and example will be a powerful method in fostering children's morals. Regarding the great example, God sent the Apostle to be the best example (Chaeruddin, 2016; Fitroh \& Sari, 2015). Muhammad is the highest example as a role model in the context of moral development.

\section{Moral Guidance to Teachers}

At least there are four indicators of students said to have good character towards the teacher, that is, they are always polite in speaking and behaving, do not argue with the teacher and always carry out the tasks given by the teacher, always help teachers in need without being asked and feel happy when following the learning process.

\section{Good practice in speaking and acting}

There is a classic suggestion expressed by Rifan (2012) that, a very noble person is a person who pioneered a moral movement that is beneficial to one generation and the next generation. The advice indicates that humans have the same opportunity to do good, especially humans who work as teachers, because the teacher is big in the eyes of his students, what is seen from his teacher will be imitated, because the child will emulate what is seen from his teacher. Exemplary has an important meaning in educating children's morals and being a central point in educating and fostering morals. If the teacher has good character, there is a possibility that the students have good character. Conversely, if the teacher has a bad character there is a possibility that the student has a bad character too.

The habit used by the teacher to educate children in the Elemantary Special School of Rejang Lebong, seems to use the exemplary method especially in fostering politeness in speaking and behaving. As the results of research data that, fostering student morals is not only when giving lesson material in class but we also do it outside of class hours, by giving examples to them like to get used to good things in speaking gently, even though sometimes there are annoying student attitudes, we must show a high level 
of patience, giving direct advice we do as an example when meeting with an older person we instruct that the child shake hands and kiss his hand.

Based on the results of research, she revealed that, the role of parents and teachers is very dominant in fostering student morals; the simplest and most effective way is for the teacher to set a good example to student. When students commit violations then that's when students get lessons and reprimands, for example when they call parents and teachers using the word "hi hi" then given an example by calling the father or mother with polite words. Every time there is a case of moral violation, then it should be reprimanded and given a lesson at that time so as not to pile up the problem, because if there are too many problems done by a student, it will be difficult to provide coaching.

The habit of carrying out the tasks given by the teacher

One of the activities in the learning process is the teacher gives assignments to students who function as exercises or evaluation materials for the level of achievement of the learning process. For children with special needs, of course there is a separate way for them to want to carry out every task given to them. Based on the results of research data in the field, found some tricks from Islamic education teachers, among them, the teacher gave assignments in a fun way such as students directed to photocopy copies of the material taught, then paste it in the exercise book they have, besides that the teacher also gave task with a very gentle way of persuading them to do their work with words that educate.

The method of persuading or seducing children in educating children is apparently very effective for children with special needs, because mentally they are eager to get praise when they do well, and do not threaten them when they make mistakes.

The habit of paying attention to the teacher when talking in and out the classroom
Reciprocal communication must occur when the learning process takes place between the teacher and students, so for children with special needs total communication is needed in conveying educational messages especially for children who have a hearing deficiency, special ways are needed to provide information to the deaf, in this spelling of the finger is very functioning to support the development of the ability to read and write. So by using the finger alphabet and supported by total communication by amplifying the sound volume can convey messages to students so that they continue to be interested to pay attention to the explanation delivered by the teacher both in and out the classroom. Likewise what is done by teachers in Elemantary Special School? According to experts that if a deaf child has mastered the spelling of the fingers, then this ability will also support the ability to read and write (Somat \& Herawati, 2004)

\section{The Habit of helping teachers who need help without being asked}

Behavior of helping others who need help in Islam is called good character, as Mucharomah (2017); Rasyid (2016) revealed, that when character is connected with Allah, then character is carrying out all the commands of Allah and away from His prohibitions with full sincerity. Allah's command that is carried out is not a burden and Allah's prohibition is shunned not because of compulsion, but all of it is lived with full awareness and sincerity.

Helping is one of the items of character recommended in Islam, so as a formal educational institution for foreign Special schools in Curup, Rejang Lebong also implements this habit in the learning process, as revealed on the results of research data, that the majority of children in this school have physical and mental limitations, but that does not mean moral guidance in terms of being accustomed to helping other people in need we don't teach, but we as teachers here provide direction so that children are sensitive and quick to help if there are teachers or other 
people who need help. The same with the results of observations, it is clearly seen that the children in this school have tremendous sensitivity in terms of helping people who need help, at that time the researcher witnessed a teacher who had just come down from the car carrying goods, and one of the children with hearing impairment rushed to help the teacher without any instructions or requests for help from his teacher, this indicates one of the habits that teachers have successfully done towards their students.

The habit of creating a sense of joy when attending Islamic religious lessons

The joy of the child while attending the lesson is happiness for a teacher, because in reality a teacher has managed to create a pleasant mood for their students. Excitement according to Ahmadi (2009) is an expression of relief that is feeling free from tension. Usually the excitement is caused by things that are suddenly (Surprise) and the excitement is usually social in nature, which involves other people around the person being excited. Creating an atmosphere of joy, it is not possible not to use a method or the method that makes a condition that can be happy, meaning there are certain factors that can make a condition that is a happy atmosphere, so it happens in class. Based on the results of research data at Special Schools in Rejang Lebong, it was clearly seen that the children in this school condition the classroom into a class that is not saturated for children by using fun learning strategies, starting from preparing everything related to learning media such as pictures, props and so on, to how the teachers delivered the material with great patience, and occasionally interspersed with light humor that tickled students so that they seemed enthusiastic about learning and excited when studying Islamic education.

\section{Fostering Student Morals on the Environment}

Giving students an understanding of how to care for the environment is an obligation for a teacher, because according to Rasyid (2016), Allah has created nature in a balanced and harmonious manner. Therefore humans are obliged to maintain the harmony of Nature. There are at least two things coaching conducted by the teacher to students in order to foster a sense of concern and maintain environmental harmony, namely:

Habituation of students to throw trash in its place

Based on the results of research data at Special Schools in Rejang Lebong, it appears that students in this school already have good habits in terms of caring for the environment as evidenced by their habit of throwing trash in the space provided, and if a violation occurs the teacher immediately makes repairs by reprimanding the student is directly at the scene, so students immediately realize that what they did was wrong. So, clean will also have a good psychological impact on activities, as revealed by Setyaka in his book the secret habits of successful people from waking up to before breakfast say, that successful people also have clean habitsclean in the morning before starting work. In other words, successful people always do it, because with cleanliness, comfort and safety in work can be enjoyed. Feeling comfortable will give a psychological feel of calm. This calmness gives a positive effect in doing work (Setyaka, 2014)

The habit of students taking care of school facilities and infrastructures

Giving an understanding to students to feel they have school facilities and infrastructures such as their own is one of the ways done by the teacher, so that students want to maintain the existing facilities and infrastructure, this is evidenced by the results of research data, it appears that facilities and infrastructure at Special Schools in Rejang Lebong is neatly maintained, there are no visible classroom doors, broken school glass, scratches on the walls of the school were not found, this is usually found in public schools, especially at the elementary school level. This shows that, there is seriousness on the part of 
the school, and the awareness of the students to maintain the facilities and infrastructure available at school.

The results of the study above, seen their seriousness to provide moral guidance to their students, meaning that learning is not only focused on the cognitive realm, where children are expected to memorize or explain the theories provided, but more than that good personality or character is emphasized to be applied by children wherever they are, and the process of coaching is done every day at school using the habituation method. In addition, the role of parents is also expected to support this habituation movement, especially parents are directly involved and witnessing how teachers provide learning to their children, because the majority of parents wait for their children until the end of class. So when there are violations committed by their children, the teacher asks parents to participate in providing guidance to their children.

The implementation of Islamic education at the Special Schools in Rejang Lebong Regency refers to the 2013 curriculum with the vision, mission and objectives of the school being designed. One of them is to make this school superior in skills and independence through inculcation of cultural and religious values. and supported by adequate learning methods and media, because educating children with special needs is very different from normal children, the teacher must be really mature in preparing teaching material, so that later students will easily understand the material delivered by the teacher in class. Especially for children with hearing impaired special needs, teachers at the Elemantary Special School of Rejang Lebong, using learning strategies in moral development is using expository strategies. Safriadi (2017) named this expository strategy with the term direct learning strategies (Direct Instruction), in this system the teacher presents material in a form that is prepared neatly, systematically and completely so that students stay listening and digesting it in an orderly and orderly manner. Students are also required to master the material that has been prepared.

Based on the results of research data, it can be explained the steps prepared by the teacher in implementing expository learning strategies as follows: 1) The teacher prepares a lesson plan; 2) The teacher prepares learning materials as complete as possible; 3 ) The teacher carries out learning by using total communication; 4) The teacher displays pictures relating to the material; 5) Students are instructed to choose the right picture for a statement; 6) Students are instructed to stick pictures into a notebook; 7) Teachers and students draw conclusions from the learning process. While a very supportive method for implementing this strategy in the classroom used by Islamic education teachers is to use modeling and training methods, bearing in mind the children who are given lessons are children with special hearing impairments, the teacher prepares materials suitable for deaf students, namely using visual media such as pictures related to the subject matter, besides that the teacher must also really understand the material being taught extensively especially the material relating to moral development, based on the results of observations made very clear that Islamic religious education teachers are able to modify the material by displaying examples that occur in real life.

So in the learning process students seem enthusiastic to follow the ongoing subject matter, this is shown when in turn students are asked to choose a picture that matches the good character and they are able to show the right choice, they do it with a happy mental condition especially when they are instructed to photograph the copy of the picture and paste it in their respective notebooks, but in the process of course the teacher who teaches must have a high level of patience, because students with conditions have limitations, especially hearing impaired sometimes they have when they like the process learning and sometimes boredom appears. 
Moral development carried out at Special Schools in Rejang Lebong Regency, is not only done formally in the classroom, but as long as students are in the school environment, using the strategy of adding hours of study with the habituation method, the teacher and parents of students who every day waiting for their children to be involved in the process of moral formation, from the results of interviews with both the teacher and the students' parents, it appears that when outside the classroom students make mistakes that violate the moral provisions, directly the teacher and student parents give a reprimand, which according to them this warning is more effective and impressing the child that this is wrong and should not be done. To increase the student's knowledge about religion, the school adopted a special policy to carry out religious activities in the school by presenting outside da'i who delivered a sermon, this is usually done at moments of Islamic holidays, such as the Birthday of the Prophet, Isra'Mi'raj and the Islamic new year, in the process of its implementation students were enthusiastic about participating in the activity.

Each learning process certainly has things that support and hinder its journey, then in Special Schools, based on interviews, documentation and observations found at least four things that support the learning process in moral development for deaf students, namely: 1) Headmaster who are in fact graduates of special service schools, are very concerned about the creation of human beings who have noble character so he fully supports any activities oriented to the formation of morals, this can be seen from the vision and mission of the school, as well as the policies taken to hold religious activities as supporting activities to realize it. 2) Teachers who teach at the Special Schools in Rejang Lebong Regency especially Islamic education teachers have the seriousness to foster student morals, even though they do not have the basic knowledge of teaching children with special needs, but through activities carried out by the school by providing guidance specifically how to teach at Special Schools, the teachers follow it well, so that when teaching they are accustomed to dealing with students with various limitations in a tenacious and patient manner. 3) Concern of students 'parents towards the progress of their children is also felt to be very supportive of the learning process especially in terms of moral development, this is in accordance with the results of an interview with one of the students' parents, that they are very supportive of the activities carried out at school, they never protest when their children reprimanded when they make mistakes and they even support their teacher by directly reprimanding when their children make mistakes. 4) Students show high enthusiasm when the learning process takes place, they learn calmly and are happy this is certainly supported by the strategies and methods of teachers who teach in their class, so that they respond positively to the teacher and the material being taught.

Then there are five components that are felt as obstacles, in the implementation of learning in the Elemantary Special School of Rejang Lebong Regency, namely; 1) The absence of a special curriculum for students with special needs so that this school uses the 2013 curriculum, the Graduation Standards, Core Competencies and Competencies are essentially equated with public schools, with this condition the teaching teacher finds it difficult to pursue it all, which ultimately teachers take the initiative to transfer knowledge adapted to the child's condition; 2) Especially for Islamic education teachers, the dominant ones who provide moral guidance to children should be religious teachers graduated from Special Service Schools, but this is not the case in this school, Islamic religious education teachers at this school who are graduates of State Islamic Institute of Curup, Rejang Lebong; 3) The learning process does not go according to a predetermined schedule, which should enter at $08.00 \mathrm{PM}$ and they go home at 12.00 PM, but at 10:00 PM on average students have asked to go home, this happens because of the limitations they have, and based on observations students do it seems that they are already getting nervous around 09.30 PM, this is due to the limitations they have, and it turns out that people with special needs, get tired 
more quickly and feel bored when compared to those who are normal; 4) Supporting facilities in learning are still lacking, this is based on observations and interviews that education in special schools will be easier if supported by means as a learning medium for example for deaf children, they are very easy to catch the message conveyed if the material is conveyed through audio, visual, or both, this is evident when getting learning with teachers who use drawing media students are very enthusiastic, it would be better if the teacher uses electronic media such as infocus, but the availability is very limited, for six classes there are only two infocus so that the teacher the teacher must take turns using it; 5) The distance between the domicile of students and the majority of schools is far, this results in frequent students not attending school, especially on rainy days and schools do not have a car as a means of transportation for students.

\section{CONCLUSIONS AND RECOMMENDATION}

The teaching strategy of Islam education teachers in moral guidance for children with special needs at Special Schools is expository strategy. In addition the strategy used is to increase the hours of study by using the habituation method. Supporting factors in the learning process are mainly moral development in Elemantary Special Schools, namely principals who are very concerned about the development of student morals, teachers who are enthusiastic in providing learning and moral guidance, and have great patience in dealing with children with special needs. Besides that, parents who play an active role in helping with moral development activities, students seem calm and happy to take lessons in class, especially when the teacher who teaches them uses media that attracts their attention so that the material delivered is easy to understand, as well as moral messages that are delivered they can receive well.

While the inhibiting factors, namely the absence of special curricula for children with special needs who study in Elemantary Special School in Rejang Lebong Regency are not teachers who are graduates of special service schools, and the lack of supporting facilities as media learning, making the learning process run monotonously. In addition, children with special needs have a tendency to get bored easily, as well as distance to the domicile of students with distant dominant schools and the lack of means of transportation between students.

\section{REFERENCES}

Afdal, G. (2008). Religious education as a research discipline: An activity theoretical perspective. British Journal of Religious Education, 30(3), 199-210.

Aron, L., \& Loprest, P. (2012). Disability and the education system. The Future of Children, 97-122.

Avramidis, E., Bayliss, P., \& Burden, R. (2000). Student teachers' attitudes towards the inclusion of children with special educational needs in the ordinary school. Teaching and Teacher Education, 16(3), 277-293.

Buhler, K. (2013). The mental development of the child: A summary of modern psychological theory. Routledge.

Carta, J. J., Schwartz, I. S., Atwater, J. B., \& McConnell, S. R. (1991). Developmentally appropriate practice: Appraising its usefulness for young children with disabilities. Topics in Early Childhood Special Education, 11(1), 1-20.

Chaeruddin, B. (2016). Cerita sebagai Metode Penanaman Nilai-Nilai Moral bagi Anak. Inspiratif Pendidikan, 5(2), 253-262.

Cook, R. E., Klein, M. D., \& Chen, D. (2015). Adapting early childhood curricula for children with special needs. Pearson. 
Dermawan, O. (2013). Strategi pembelajaran bagi anak berkebutuhan khusus di slb. Psympathic: Jurnal Ilmiah Psikologi, 6(2), 886-897.

DeVore, S., \& Russell, K. (2007). Early childhood education and care for children with disabilities: Facilitating inclusive practice. Early Childhood Education Journal, 35(2), 189-198.

Farokhi, M., \& Hashemi, M. (2011). The analysis of children's drawings: Social, emotional, physical, and psychological aspects. ProcediaSocial and Behavioral Sciences, 30, 2219-2224.

Fitroh, S. F., \& Sari, E. D. N. (2015). Dongeng sebagai media penanaman karakter pada anak usia dini. Jurnal PG-PAUD Trunojoyo: Jurnal Pendidikan Dan Pembelajaran Anak Usia Dini, 2(2), 95-105.

Galindo, L., Maginnis, T., Wallace, G., Hansen, A., \& Sylvestre, D. (2007). Education by peers is the key to success. International Journal of Drug Policy, 18(5), 411-416.

Guha, M. L., Druin, A., \& Fails, J. A. (2008). Designing with and for children with special needs: An inclusionary model. Proceedings of the 7th International Conference on Interaction Design and Children, 61-64.

Hager, A. D., \& Runtz, M. G. (2012). Physical and psychological maltreatment in childhood and later health problems in women: An exploratory investigation of the roles of perceived stress and coping strategies. Child Abuse \& Neglect, 36(5), 393-403.

Harahap, R. M. (2019). Pendidikan dan peradaban dalam narasi sejarah Islam klasik: korelasi dan koneksi. Idrak: Journal of Islamic Education, 2(1).

Hastings, R. P., \& Oakford, S. (2003). Student teachers' attitudes towards the inclusion of children with special needs. Educational Psychology, 23(1), 87-94.

Holley, R. (2016). Religious education and religious understanding: An introduction to the philosophy of religious education. Routledge.

Ihsani, N., Kurniah, N., \& Suprapti, A. (2018). Hubungan metode pembiasaan dalam pembelajaran dengan disiplin anak usia dini. Jurnal Ilmiah Potensia, 3(2), 105-110.

Jaya, A. (2012). Psikologi Pendidikan dan Pengajaran Teori dan Praktik. Yogyakarta: CAPS.

Johnson, D. W., \& Johnson, R. T. (2011). Cooperative learning. The Encyclopedia of Peace Psychology.

Katsir, I. (2004). Tafsir Ibnu Katsir Jilid 5. Terj. Salim Bahreisy Dan Said Bahreisy.

Lipman, M. (2003). Thinking in education. Cambridge University Press.

Mahabbati, A. (2014). Kebijakan, implementasi dan isu strategis pendidikan bagi individu berkebutuhan khusus. Jurnal Pendidikan Islam, 3(1), 31-46.

Maskur, M. (2019). Seni baca Al-quran: Metode efektif dalam pembelajaran Al-quran Hadits. Quality, 7(2), 100113.

Morton, D. D. (2000). Beyond parent education: The impact of extended family dynamics in deaf education. American Annals of the Deaf, 359365.

Mucharomah, M. (2017). Guru di era milenial dalam bingkai rahmatan lil alamin. Edukasia Islamika, 172-190.

Mumtahanah, N. (2011). Gagasan Hasan Langgulung Tentang Pendidikan 
Islam. Al Hikmah: Jurnal Studi Keislaman, 1(1), 4-4.

Nesbitt, E. M. (2004). Intercultural education: Ethnographic and religious approaches. Sussex Academic Press Brighton.

Nugroho, A., \& Mareza, L. (2016). Model dan Strategi Pembelajaran Anak Berkebutuhan Khusus dalam Setting Pendidikan Inklusi. Jurnal Pendidikan Dasar Perkhasa: Jurnal Penelitian Pendidikan Dasar, 2(2), 145-156.

Pivik, J., McComas, J., \& Laflamme, M. (2002). Barriers and facilitators to inclusive education. Exceptional Children, 69(1), 97-107.

Powers, S. (2002). From concepts to practice in deaf education: A United Kingdom perspective on inclusion. Journal of Deaf Studies and Deaf Education, 7(3), 230-243.

Rafferty, Y. (2008). The impact of trafficking on children: Psychological and social policy perspectives. Child Development Perspectives, 2(1), 1318.

Rahardja, D. (2016). Pendidikan Luar Biasa dalam Perspektif Dewasa Ini. Jassi Anakku, 9(1), 76-88.

Rahayu, S. M. (2013). Memenuhi Hak Anak Berkebutuhan Khusus Anak Usia Dini Melalui Pendidikan Inklusif. Jurnal Pendidikan Anak, 2(2).

Rahmi, M. (2019). Penggunaan metode cerita dalam penanaman nilai-nilai akhlak anak. Al Abyadh, 2(2), 45-52.

Rasyid, M. M. (2016). Islam Rahmatan lil Alamin Perspektif KH. Hasyim Muzadi. Episteme: Jurnal Pengembangan Ilmu Keislaman, 11(1), 93-116.
Rifan, A. R. (2012). Hidup Sekali, Berarti, Lalu Mati. Elex Media Komputindo.

Safriadi, S. (2017). Prosedur Pelaksanaan Strategi Pembelajaran Ekspositori. Jurnal Mudarrisuna: Media Kajian Pendidikan Agama Islam, 7(1), 47-65.

Seriti, N. N., Candiasa, I. M., Kom, M. I., \& Natajaya, I. N. (2013). Pengaruh Strategi Pembelajaran Heuristik Dan Algoritmik Terhadap Hasil Belajar Teknologi Informasi Dan Komunikasi (TIK) Jurnal Administrasi Pendidikan Indonesia, 4(1).

Setyaka, H. (2014). Rahasia kebiasaan orang-orang sukses sejak bangun pagi hingga sebelum sarapan. Yogyakarta: Diva Press.

Slavin, R. E. (1987). Cooperative learning and the cooperative school. Educational Leadership, 45(3), 7-13.

Swanwick, R., \& Marschark, M. (2010). Enhancing education for deaf children: Research into practice and back again. Deafness \& Education International, 12(4), 217-235.

Syahrizal, D., \& Sugiarto, A. (2013). Undang-Undang Sistem Pendidikan Nasional \& Aplikasinya. Jakarta, Laskar Aksara, Cet.

Vermeer, P. (2010). Religious education and socialization. Religious Education, 105(1), 103-116.

Wauters, L. N., \& Knoors, H. (2008). Social integration of deaf children in inclusive settings. Journal of Deaf Studies and Deaf Education, 13(1), 21-36.

Wilkens, C. P., \& Hehir, T. P. (2008). Deaf education and bridging social capital: A theoretical approach. American Annals of the Deaf, 153(3), 275-284. 